\title{
COMMUNITY RESPONSES OF NORTH BANDUNG SUBURBS TO LAND CONVERSION
}

\author{
Lili Somantri \\ Sains Informasi Geografi (SAIG), Universitas Pendidikan Indonesia \\ Jl. Setia Budi No. 229 Sukasari, Bandung, Jawa Barat, 40154, Indonesia \\ e-mail: lilisomantri@upi.edu
}

Received: 20 April 2020, Repaired: 08 July 2021, Approved: 19 July 2021

\begin{abstract}
Abstrak
Pinggiran utara Kota Bandung merupakan daerah perluasan dari perkembangan Kota Bandung. Perkembangan wilayah di wilayah pinggiran kota dapat menimbulkan masalah alih fungsi lahan. Tujuan dari penelitian ini adalah untuk mengidentifikasi respon masyarakat dan faktor-faktor alih fungsi lahan di pinggiran utara Kota Bandung. Metode deskriptif kuantitatif digunakan melalui penyajian persentase dan hasil wawancara dengan 108 responden. Temuan menunjukkan bahwa respon masyarakat terhadap konversi lahan menunjukkan respon positif dan negatif. Di antara tanggapan positif adalah bahwa konversi lahan dianggap sesuai untuk pembangunan daerah; pembangunan jalan dapat meningkatkan mobilitas warga dan menciptakan lapangan kerja. Sementara itu, di antara tanggapan negatif adalah bahwa alih fungsi lahan dapat mengakibatkan suhu panas, ladang tandus, kelembaban, kekurangan sumber air, dan hilangnya lahan pertanian. Faktor-faktor yang mempengaruhi alih fungsi lahan antara lain pertumbuhan penduduk, perkembangan kawasan Kota Bandung, pembangunan pemukiman dan kawasan wisata, kenaikan harga tanah, dan faktor sosial budaya masyarakat Sunda.
\end{abstract}

Kata kunci: respon masyarakat, faktor alih fungsi lahan, pinggiran kota Bandung utara, alih fungsi lahan

\begin{abstract}
The northern suburbs of Bandung City are an expansion area of the development of Bandung City. The regional development in suburban areas can cause land conversion problems. The objective of the present study was to identify the community's response and the factors of land conversion in the northern suburbs of Bandung City. A descriptive quantitative method was employed through the presentation of percentages and the results of interviews with 108 respondents. Findings reveal that the people's responses to land conversion exhibited positive and negative responses. Among the positive responses were that land conversion was perceived appropriate for regional development; road construction could increase citizen mobility and create job opportunities. Meanwhile, among the negative responses were that land conversion could result in hot temperatures, barren fields, humidity, lack of water sources, and the loss of agricultural land. The factors affecting land use conversion included population growth, the development of the Bandung City area, construction of residential and tourist areas, increased land prices, and socio-cultural factors of the Sundanese people.
\end{abstract}

Keywords: community response, land function conversion factors, suburbs of the north of Bandung, land function conversion

\section{INTRODUCTION}

Land is a crucialnatural resource in human lifewhere humans utilize it to ensure their sustainability. Consequently, all their activities cannot be separated from the land as a place where all activities are taking place, such as farming and animal 


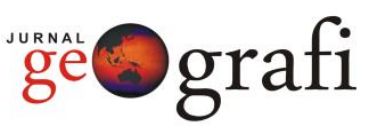

husbandry to meet the needs of the food, homes for a place to stay, a network of roads for the needs of mobility to sell goods and services, and aregional tour $t$ o meet the needs of recreation and leisure. Developing land in an area can provide an opportunity for the region to grow in the future (Noviyanti, Pravitasari, and Sahara, 2020). The use of the land must be in line with development priorities so that its use is optimal and does not cause harmful effects. Land use is to be based on the level of support of the district, so there exists a need for structuring the proper use of land to avert damage (Lestari, \& Simanungkalit, 2012).

Land use varies from one place to another, depending on the natural and human conditions. Areas with hilly and mountainous landscapes can be used as dryland agriculture. Meanwhile, areas with plain landscapes can be used to build a city as a center for human activities. In addition, human conditions affecting land use are livelihoods and population. A community whose livelihood is farming will use the land for agricultural activities, whereas those in the service sector will utilize the land for service activities.

Land use is also closely related to population growth. Population growth in an area will require new space as land for settlements (Sitompul, 2016). Increasing population growth will have an effect on the increased need for a place to live (Dewi \& Rudiarto, 2013; Prihatin, 2016). The need for land to be built as a living place will prompt the demand for land to rise. Such a demand for land has continued to increase from time to time, while the available land is limited (Indrianawati \& Mahdiyyah, 2019). Land use must refer to the functional dimensions of the area, namely economic use, agricultural or forest settlements, and nature conservation (Mandala, Indarto, Arifin, \& Hakim, 2020).

Land conversion is a land condition whose function has changed and usually leads to various problems, especially environmental problems. This land conversion is generally found in urban or suburban areas. The process of land conversion is unavoidable in every developing area (Janah et al., 2017). One that can be used as an indicator of urban development is a change in the function of land use from vegetated land to built-up land or from agricultural land to built-up land both as residential land and infrastructures such as roads, industrial centers, and so on (Lumbantoruan, 2010).

Land use conversion can be seen from multiple aspects. First, based on the actors, land conversion can be performed directly by the landowner to fulfill life needs such as housing needs and business capital needs. Such a conversion tends to be random, small, and scattered. The impact of land conversion will emerge after a long period of time (Sumaryanto et al., 2005). Land conversion that does not pay attention to land conditions can create critical land (Berutu, 2013). The trend of land conversion from year to year continues to rise in various regions; however, what often occurs, in general, is the conversion of agricultural land to nonagricultural purposes (Marinda, Sitorus, \& Pribadi, 2020). It is noted that agricultural land in Indonesia is shrinking by 100,000 ha/year (Hidayat, 2020). Specifically, the negative impacts of land conversion from agriculture to nonagriculture include: first, national food security support is declining. The reduction in rice production due to the conversion of paddy fields is permanent. Once the rice fields are converted, such is irreversible. Second, the income of farmers decreases, and the poverty of local communities increases. Conversion of paddy fields causes the loss of livelihoods for farmers and farm laborers, which leads to a rise in poverty rates. Third, investment is waste such as high-cost irrigation. Fourth, the rice field ecosystem is destroyed. For tropical areas, in the rainy season, rice fields function not only for rice cultivation but also as an effective ground surface to accommodate excess rainwater (Sumaryanto et al., 2005).

There are six factors causing land conversion from agriculture to nonagriculture: first is the population, namely 
with an increase in population, the demand for land also increases, both for settlements, industry, services, trade, road networks, recreation areas, and other public facilities. Second is the economy, namely the high price of land due to nonagricultural activities compared to agriculture. In addition, the low income of farmers encourages farmers to sell their land for family needs and business capital needs. The third is the socio-cultural factor, namely inheritance laws causing fragmented agricultural land to be less profitable because of the narrow land. Fourth is environmental degradation, such as lack of water for agriculture, environmental pollution, and seawater intrusion, which causes the utilization of agricultural land to be unideal. The fifth is regional autonomy, which is only concerned with short-term benefits such as increasing regional original income so that it does not calculate longterm benefits and national interests to meet national food needs. Sixth is the weakness of law enforcement, such as the absence of strict sanctions against perpetrators of land destruction, the government's inconsistency in permitting regional spatial plans, or the low willingness of local governments to consistently protect agricultural land (Isa, 2006).

The phenomenon of land use conversion is primarily found in suburban areas. Ironically, the land undergoing conversion is the most fertile in Indonesia, namely the land on the island of Java which serves as the rice barn of Indonesia (Hossaimah \& Subari, 2017). Land conversion has various impacts, such as changes in ecological stability, soil stability, as well as the socio-economic conditions of land owners (Kusdiane, Soetarto, \& Sunito, 2018). Conversion in land use will also more or less contribute to severe land damage disasters (Masyuri, 2018). In some cases, intentional land conversion can trigger the surrounding land to also change function progressively (Purwanti, 2018). Many suburban areas are caused by the mounting pressure of urban activities, namely converting agricultural land to non- agriculture (Giyarsih, 2010). In addition, the impacts of the conversion of agricultural land include the threat of food security and the socio-cultural implications of the community, namely the shift of agrarian society as a cultural identity of Indonesian society to become an industrial society (Nurchamidah, \& Djauhari, 2017). To minimize the negative impacts, land conversion should take into account aspects of land suitability and land carrying capacity. The element of land suitability and its carrying capacity is pivotal in development (Sillia \& Yuliastuti, 2020). The government has issued guidelines regarding land use so as not to cause disasters, namely by not damaging either directly or indirectly the physical, chemical, biological nature of the environment that exceeds the standard criteria for environmental damage (As'ari, Mulyanie, \& Rohmat, 2019).

Previous research on the relationship between land conversion and community was carried out by Iqbal and Sumaryanto (2007), who found that uncontrolled conversion of agricultural land could threaten food supply capacity, and in the long term, could cause social losses. Land conversion control can involve active community participation. Saputra and Budhi's (2015) study shows that land conversion has an impact on increasing unemployment, reducing income levels, decreasing welfare levels, increasing poverty and damage. A similar survey conducted by Mahardika and Mutaali (2018) on the impact of land conversion on the socio-economic conditions of the community indicated that land conversion does not affect the economic situation of the community because there is only a process of transfer of power of property inherited to the landowner's family. Among the undesirable impact of land, conversion is increased vulnerability to traffic accidents.

In general, the Greater Bandung area has experienced a significant increase in population from year to year, which brings implications for increased development and higher demand for land (Supriyatin, Pravitasari, \& Pribadi, 2020). The suburbs of 


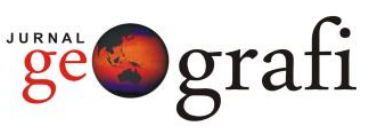

Bandung continue to experience a decline in the amount of agricultural land every year. The conversion of agricultural land in the city of Bandung from 2011 to 2015, based on the data on permits for technical considerations of land, reaches 4,235,432 m2 or 423.5432 hectares. The conversion of agricultural land has been dominant in the suburbs of Bandung City, punctuated by the conversion of agricultural land to nonagriculture. Thus, it is necessary to examine the relationship between land value and the availability of agricultural land on the outskirts of Bandung (Rachma, 2016). Such a recommendation is reinforced by the data in the Bandung Regency Long-Term Regional Development Plan of 2005-2025 as a suburb bordering the City of Bandung, according to which the main problems in the field of spatial planning in Bandung Regency are land conversion, the low ratio of green open space (only $0.22 \%$ ), and illicit land use. This is due to the unavailability of a regional regulation on the detailed layout plan for urban areas as a guide in planning and utilizing space, ineffectual monitoring and controlling on space utilization, and the absence of a master plan for strategic areas as a reference for controlling space utilization.

The northern suburbs of Bandung City are part of the North Bandung Region (NBR) which constitutes parts of Bandung Regency, Bandung City, Cimahi City, and West Bandung Regency. To the north and east of the North Bandung area is a series of mountains, namely Mount Burangrang, Masigit, Gedongan, Sunda, Tangkuban Parahu and Manglayang. As for the south and west, it is bordered by a contour line with an altitude of 750 meters above sea level (Regulation of the Governor of West Java Number 30 of 2008 concerning Implementation Guidelines for Controlling Spatial Utilization of the North Bandung Area in the Bandung Regency and West Bandung Regency, 2008).

Community response is the community behavior or attitude towards the phenomena that occur in the surrounding environment. A response begins with a person's attitude to a specific stimulus. Factors influencing responses can be physical stimuli or conditions of the observer, such as past experiences or moods (functional variables). Three factors influence a person's response. The first is oneself, namely the person concerned sees and gives his/her interpretation of what $\mathrm{s} /$ he sees. The person's interpretation is influenced by attitudes, motives, interests, and expectations. The second is the object of response, the target being responded to can be in the form of people, things, or events. The third is the situation, namely the condition that causes the response. This response can be a positive response or a negative response. Someone who has a positive response can be reflected from the cognitive, affective, and psychomotor abilities. Conversely, someone is deemed to have a negative response if the information $\mathrm{s} /$ he hears or changes that occur in an object does not affect his/her actions.

Therefore, it is of empirical interest to conduct research related to community responses to land use conversion in the northern suburbs of Bandung City and the factors behind the transformation. To fill the research gap, this study sought to examine the community's response in more depth and provides a specific description of the community's response to land conversion on the outskirts of the city Bandung.

\section{RESEARCH METHODS}

This descriptive study sought to offer a factual portrayal of the community's responses to land use conversion. A survey method was employed with interviews as a means of collecting data. This research was conducted in the northern suburbs of Bandung City, which includes Cimenyan, Lembang, and Parongpong sub-districts as the regional population.

The sample of respondents amounted to 108 people taken by accident evenly from all the sample villages of the region. The sample areas comprised villages bordering the city of Bandung, namely Cimenyan District (Cibeunying, Ciburial, Cikadut, Cimenyan, Mandalamekar, 
Mekarsaluyu, Padasuka, and Sindanglaya villages), Lembang District (Cikahuripan, Lembang, Mekarwangi, Pagerwangi, and Wangunsari villages), and Parongpong District (Ciwaruga and Cihideung villages).

The data analysis technique was descriptive quantitative from the results of interviews with respondents. This analytical technique attempted to explain the data from the field in the form of percentages. The community's responses to land conversion and the factors behind the conversion were then enumerated and deliberated with related references.

\section{RESULTS AND DISCUSSION Geographical condition of the research areas}

In general, the North Bandung area has a hilly topography with an altitude between $700 \mathrm{~m}$ above sea level $-1700 \mathrm{~m}$ above sea level, which is the hillside of a series of Mount Burangrang, Tangkuban Parahu, and Bukitunggul. This topography stretches from Cisarua District in the west, Parongpong, Lembang, Cimenyan, and Cilengkrang. To the southern part of the city of Bandung and the city of Cimahi, the topography is sloping. The topography in Lembang District is a vast plain because it results from the Lembang Fault subsidence process.

The soil types in the North Bandung area consist of andosol, latosol, and regosol. The latosol soil type is located at an altitude of 300-900 meters above sea level; has a thick solum (1-5 meters); is red brown to yellowish and has a clay texture with a crumb structure. This type of soil is widely used for rice, secondary crops, vegetables, and sweet potatoes. Meanwhile, the andosol soil type is widely used for vegetable crops, flowers, tea, and quinine.

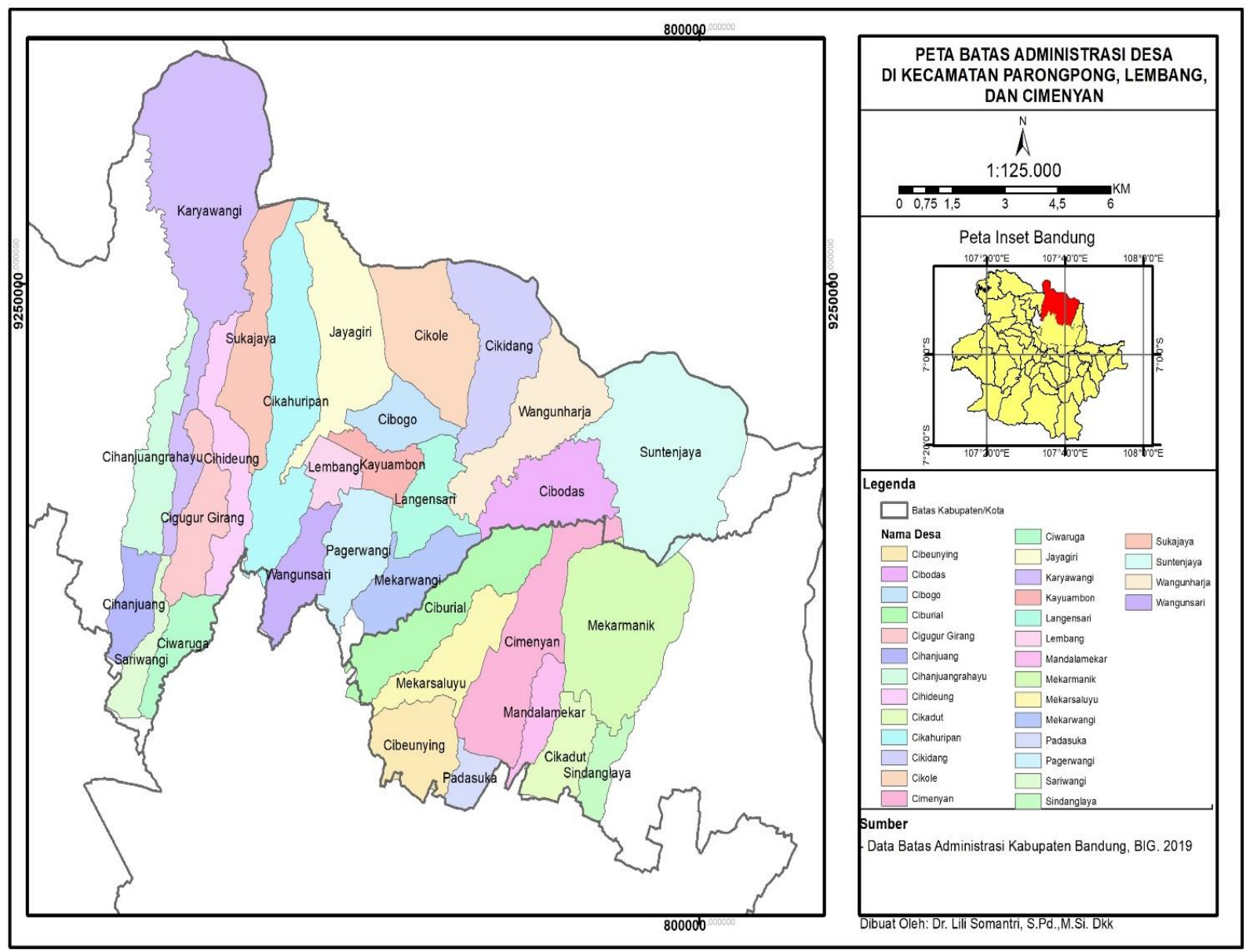

Figure 1. Map f the Research Areas 
Socio economic conditions of the respondents

Based on the survey results obtained from 108 respondents, the age group of respondents was dominated by 41-50-yearolds with a total percentage of $31.48 \%$, followed by $51-60$-year-olds with $25.93 \%$. Meanwhile, the age group of $<30$ years had the least with a total percentage of $4.63 \%$. More details can be seen in the following table.

Table 1. Respondents' age

\begin{tabular}{rcrrrrrrrr}
\hline & \multicolumn{1}{c}{ Districts (person) } & & & \\
No & $\begin{array}{c}\text { Age } \\
\text { (years) }\end{array}$ & Parongpong & $\%$ & Lembang & $\%$ & Cimenyan & $\%$ & Total & $\%$ \\
\hline 1 & $<30$ & 0 & 0 & 2 & 6,45 & 3 & 4,92 & 5 & 4,63 \\
2 & $31-40$ & 2 & 12,5 & 7 & 22,58 & 16 & 26,23 & 25 & 23,15 \\
3 & $41-50$ & 9 & 56,25 & 9 & 29,03 & 16 & 26,23 & 34 & 31,48 \\
4 & $51-60$ & 4 & 25 & 7 & 22,58 & 17 & 27,87 & 28 & 25,93 \\
5 & $>60$ & 1 & 6,25 & 6 & 19,35 & 9 & 14,75 & 16 & 14,81 \\
& Total & 16 & 100 & 31 & 100 & 61 & 100 & 108 & 100 \\
\hline
\end{tabular}

Source: The results of field survey, 2019.

Based on the survey results on the last education of the respondents, the respondents whose last education was elementary school dominated with a percentage of $49.07 \%$. The second was high school education with a percentage of $28.70 \%$, while only one respondent completed undergraduate education with a percentage of $0.93 \%$. More details can be seen in the following table.

Table 2. Last education

Districts (person)

No Last education Parongpong $\%$ Lembang $\%$ Cimenyan $\%$ Total $\%$

\begin{tabular}{rlrrrrrrrr}
1 & Elementary & 4 & 25 & 19 & 61,29 & 30 & 49,18 & 53 & 49,07 \\
2 & Junior high & 7 & 43,75 & 7 & 22,58 & 9 & 14,75 & 23 & 21,30 \\
3 & Senior high & 5 & 31,25 & 5 & 16,13 & 21 & 34,43 & 31 & 28,70 \\
4 & Undergraduate & 0 & 0 & 0 & 0,00 & 1 & 1,64 & 1 & 0,93 \\
& Total & 16 & 100 & 31 & 100 & 61 & 100 & 108 & 100 \\
\hline
\end{tabular}

Source: The results of field survey, 2019.

Based on the survey results on occupations, $45.37 \%$ of the respondents were entrepreneurs, followed by housewives with a percentage of $17.59 \%$. Five of the 108 respondents were unemployed. More details can be seen in the following table.

Table 3. Respondents' occupation

\begin{tabular}{llrrrrrrrr}
\hline \multirow{2}{*}{ No } & Occupation & \multicolumn{1}{c}{ Districts (person) } \\
& & Parongpong & $\%$ & Lembang & $\%$ & Cimenyan & $\%$ & Total & $\%$ \\
\hline 1 & laborer & 3 & 18,75 & 2 & 6,45 & 7 & 11,48 & 12 & 11,11 \\
2 & housewife & 0 & 0 & 9 & 29,03 & 10 & 16,39 & 19 & 17,59
\end{tabular}




\begin{tabular}{|c|c|c|c|c|c|c|c|c|c|}
\hline 3 & $\begin{array}{l}\text { private } \\
\text { sector } \\
\text { employee }\end{array}$ & 0 & 0 & 3 & 9,68 & 3 & 4,92 & 6 & 5,56 \\
\hline 4 & farmer & 4 & 25 & 4 & 12,90 & 3 & 4,92 & 11 & 10,19 \\
\hline 5 & civil servant & 0 & 0 & 1 & 3,23 & 1 & 1,64 & 2 & 1,85 \\
\hline 6 & unemployed & 0 & 0 & 1 & 3,23 & 4 & 6,56 & 5 & 4,63 \\
\hline 7 & trader & 0 & 0 & 2 & 6,45 & 0 & 0,00 & 2 & 1,85 \\
\hline 8 & stock farmer & 0 & 0 & 2 & 6,45 & 0 & 0,00 & 2 & 1,85 \\
\hline 9 & entrepreneur & 9 & 56,25 & 7 & 22,58 & 33 & 54,10 & 49 & 45,37 \\
\hline & Total & 16 & 100 & 31 & 100 & 61 & 100,00 & 108 & 100 \\
\hline
\end{tabular}

Source: The results of field survey, 2019

Based on the results of a survey on resident status, the number of local and incoming residents was even with a total percentage of 50:50. Many incoming residents come from other districts and cities in West Java with different backgrounds.

Table 4. Resident status

\begin{tabular}{rlcccccccc}
\hline No & $\begin{array}{l}\text { Resident } \\
\text { status }\end{array}$ & Parongpong & $\%$ & Lembang & $\%$ & Cimenyan & $\%$ & Total & $\%$ \\
\hline 1 & $\begin{array}{l}\text { Incoming } \\
\text { resident }\end{array}$ & 3 & 18,75 & 11 & 35,48 & 40 & 65,57 & 54 & 50,00 \\
2 & $\begin{array}{l}\text { Local } \\
\text { residents }\end{array}$ & 13 & 81,25 & 20 & 64,52 & 21 & 34,43 & 54 & 50,00 \\
& Total & 16 & 100 & 31 & 100 & 61 & 100 & 108 & 100 \\
\hline
\end{tabular}

Source: The results of field survey, 2019.

Community Response in the Northern Suburbs of Bandung (Cimenyan District)

Of 108 respondents, 56 supplied a positive response to conversion in land use, and 52 gave a negative response. The positive responses from the respondents were highly diverse, ranging from land conversion causing a decrease in wild animals created a sense of security and ease to earn a living, to the surrounding environment became more crowded. Despite giving a positive response, the respondents also suggested that land be not wholly converted into a settlement, a tourist attraction, and so on. Meanwhile, the negative responses given by respondents comprised the environmental impact, i.e., barren and less green fields owing to land conversion, the loss of jobs, etc.

Table 5. Community response to land conversion

\begin{tabular}{|c|c|c|c|c|c|c|c|c|c|}
\hline \multirow{2}{*}{ No } & \multirow{2}{*}{ Responses } & \multicolumn{6}{|c|}{ Districts (person) } & \multirow{2}{*}{ Total } & \multirow{2}{*}{$\%$} \\
\hline & & Parongpong & $\%$ & Lembang & $\%$ & Cimenyan & $\%$ & & \\
\hline 1 & Positive & 8 & 50 & 17 & 54,84 & 31 & 50,82 & 56 & 51,85 \\
\hline \multirow[t]{2}{*}{2} & Negative & 8 & 50 & 14 & 45,16 & 30 & 49,18 & 52 & 48,15 \\
\hline & Total & 16 & 100 & 31 & 100 & 61 & 100 & 108 & 100 \\
\hline
\end{tabular}

Source: The results of field survey, 2019 


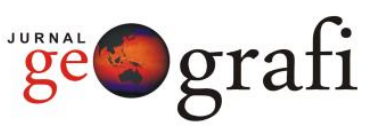

The respondents from Cimenyan sub-district were the residents of Cibeunying, Ciburial, Cikadut, Cimenyan, Mandalamekar, Mekarsaluyu, Padasuka, and Sindanglaya villages. The community's response to land conversion in Cibeunying Village varied. Some said it was good because it is for regional development; wild animals are diminishing, so it is safer, and income also increases. Others remarked that the surrounding temperature is getting hotter due to a lack of reforestation; business is complicated, and farmers lose their jobs, so that many are unemployed. Some people in Ciburial Village stated that it was better in the past because the air was cold, unlike now. Land conversion led to the loss of rice fields as a source of food needs and a source of livelihood for residents. In addition, others felt that opening the area was quite profitable because they could earn a living by trading around Dago Pakar to increase their income.

Some respondents in Cikadut Village said that the conversion of agricultural land had caused an increase in the number of residents and settlements in their area. This harmed the surrounding area so that reforestation was crucial. Currently, many were building houses without any permit yet. Land conversion was driven by economic needs. In addition to the negative impacts, positive impacts were reported, namely, areas that were once quiet become crowded. In Cimenyan Village, the respondents stated that they agreed because the change of agricultural land into settlements made accessibility easier; settlements were built so that they could become safer, well-maintained, and crowded. Near the settlements, the plantation would be more manageable. Some respondents suggested that it would be better to stop converting the area due to the loss of green land, leading to barren fields and hotter temperatures. If land is used as a factory, they are quite worried about the waste it produces so that it harms the surrounding community. More settlements or factories may mean more pollution. This is an unwelcome transformation because it will be more challenging to meet their ends.

The residents of Mandala Mekar Village said that land conversion from agriculture to settlements had rendered the area more well-maintained and safer. According to the government, such a conversion is acceptable as long as it sticks with the green open space regulations, 30\% for buildings and $70 \%$ for green open spaces. Some respondents expressed their disagreement on land conversion into a settlement because a green area functions as a water catchment area. If there is not enough reforestation, there will be a drought. They objected to the conversion because agricultural land and plantations make the area cooler and more comfortable. Plenty of trees are needed for water absorption. The rest of the respondents stated that the conversion is acceptable because there are still many agricultural lands, and the presence of houses is not too disturbing. The conversion is also welcome as long as it is in line with the government policies on green land.

The respondents from Mekarsaluyu Village believed that there were vast agricultural and plantation lands in the past, but now there remains a few, and most of them have turned into settlements. There are fewer rice fields and more settlements. Currently, many new residents - some had sibling ties with the locals, and some did not. Now the village is becoming crowded with residents and cars. However, the land is now barren, crowded with humans, and the natural landscape has been replaced with settlements. The respondents in Padasuka Village argued that land use conversion from agriculture to non-agriculture causes water catchment areas to decrease so that water supply becomes an issue. The region is currently arid, not fresh anymore. The land is presently being densely populated and crowded. The respondents suggested that development should have a permit and consider water catchment areas as well as the need and availability of land. The residents of Sindanglaya Village pointed out that currently, many city people came there 
to build houses. The conversion of agricultural land into settlements causes the neighborhood to be more crowded than in the past. However, the environmental conditions were more comfortable in the past. As a negative impact of the conversion, agricultural land is shrinking, prompting urbanization to cities. One of the key factors that causes land conversion is modernization.

\section{Community Response in the Northern Suburbs of Bandung (Lembang District)}

The respondents in Lembang District were the residents of the villages of Cikahuripan, Lembang, Mekarwangi, Pagerwangi, and Wangunsari. The community in Cikahuripan Village said they disagreed with the conversion of agricultural land to non-agriculture because of reduced agricultural land. If there is a change in land use, the farming community will find it challenging to find jobs. However, the respondents in Lembang Village said that with these changes, there was progress in an area, losses emerge that could result in unemployment for the farming community. According to the respondents in Mekarwangi Village, the conversion has a positive impact, namely opening up employment opportunities for the surrounding community. As the area gets denser because more people are coming, many neighbors and the surrounding community get jobs. However, the negative impact is that the conversion can cause air, water, and soil pollution. In addition, it also causes the air temperature to become hotter because the beautiful agricultural land has been used as a settlement.

The people in Pagerwangi Village remarked that the conversion of agricultural land to non-agriculture brought a negative impact, namely, natural conditions are no longer as natural as they used to be. With the reduction of agricultural land, people who worked as farm laborers are confused looking for jobs. Many built tourist areas do not provide a reciprocal positive impact on the surrounding community. In addition, some respondents stated that there is no problem with land conversion because the community needs a place to live. The positive impact of land use conversion is that the environment becomes more crowded because many newcomers live in this area. The respondents in Wangunsari Village asserted that the conversion of agricultural land into a tourist area had a positive impact because the local community could get jobs in the tourist area. However, there are negative impacts, i.e., the loss of farmers' livelihoods with diminishing income so that farmers incur losses. Diminishing agricultural land can reduce sources of staple food.

\section{Community Response in the Northern Suburbs of Bandung (Parongpong District)}

The respondents in Parongpong District come from Ciwaruga and Cihideung villages. The community in Cihideung Village said that agricultural land should not change because it is the work area of the people who make a living as farmers. Agricultural land must be left as a source of livelihood. The people in Ciwaruga Village affirmed that with the conversion of agricultural land into settlements, especially elite settlements, it was difficult for the poor to get land to live in, so they chose to rent out. However, other respondents said they agreed with land conversion into settlements because many need a place to live, especially for migrants who have jobs in the area. Others said they would abide by the government policies on changes in land use. Some claimed that the rice fields and gardens should never be converted because they were a source of livelihood for farmers.

\section{Factors of Land Conversion in Cimenyan District}

The results of a survey of the factors causing changes in land use in the northern city of Bandung reveal that there are six factors behind land conversion. 108 respondents stated that the population factor was the dominant factor with $44.44 \%$, followed by the economic factor with $38.89 \%$. According to the respondents, 
environmental degradation and regional autonomy factors were the smallest factors causing changes in land use.

Table 6 . Factors behind land conversion according to the respondents

\begin{tabular}{llcccccccc}
\hline \multirow{2}{*}{ No } & \multicolumn{1}{c}{ Factors } & Parongpong & $\%$ & Lembang & $\%$ & Cimenyan & $\%$ & Total & $\%$ \\
\hline 1 & Population & 8 & 50 & 9 & 29,03 & 31 & 50,82 & 48 & 44,44 \\
2 & Economy & 8 & 50 & 17 & 54,84 & 17 & 27,87 & 42 & 38,89 \\
3 & $\begin{array}{l}\text { Socio-culture } \\
4\end{array}$ & 0 & 0 & 2 & 6,45 & 9 & 14,75 & 11 & 10,19 \\
& $\begin{array}{l}\text { Environmental } \\
\text { degradation }\end{array}$ & 0 & 0 & 1 & 3,23 & 1 & 1,64 & 2 & 1,85 \\
5 & $\begin{array}{l}\text { Regional } \\
\text { autonomy }\end{array}$ & 0 & 0 & 0 & 0,00 & 2 & 3,28 & 2 & 1,85 \\
& $\begin{array}{l}\text { Law } \\
\text { enforcement }\end{array}$ & 0 & 0 & 2 & 6,45 & 1 & 1,64 & 3 & 2,78 \\
$\quad$ & 16 & 100 & 31 & 100,00 & 61 & 100,00 & 108 & 100,00 \\
\hline
\end{tabular}

Source: The results of field survey, 2019.

Among the factors causing land conversion, according to the community in Cimenyan District, Cibenying Village, are many incoming residents from outside the area, especially from the city, the development of the surrounding area, natural population growth in the area, natural population growth in Bandung City, and high land prices in Bandung City. Meanwhile, the community in Ciburial Village felt that many land conversions were caused by the investors who turned the land around the forest into a tourist spot. In addition, many foreign investors turned the surrounding area into a villa and hotel area.

The community in Cikadut Village stated that land use changes are due to economic factors, the need for housing, and current natural developments. In Cimenyan Village, land use change is due to many incoming residents who need land for housing. Vacant lands are not converted into settlements. Current developments require life to be more modern. Thus, the need for land continues to rise. In addition, the increasing number of residents need land for housing because they do not want to be away from their extended family.
The people in Mandala Mekar Village asserted that land conversion occurs because many residents need land for housing and are looking for cheap land prices. Low land prices are usually garden land. With the increasing number of residents along with population growth, the conversion of land into settlements becomes unavoidable. This is due to the lack of land for housing. Meanwhile, the respondents in Mekar Saluyu Village claimed that land use change was due to the large number of children who did not want to live far from their parents, so they looked for land close to their parents' homes. On average, the local population has many children, so the plantation land becomes a place to live. In addition, because of the large number of incomers, they have replaced plantations with settlements. These incomers come to the village because they have relatives in the village, so they are invited to live near their relatives. When these incoming residents feel comfortable, they will bring their relatives from their place of origin to move to this area, rendering vegetations to be settlements. Another factor is the construction of luxury settlements such as 
the Dago Resort, making many residents willing to sell their land because they need money.

The respondents in Padasuka Village remarked that land use change had taken place because many residents were tempted to sell their land, obtain capital from the outside, and follow modernization. The increase in population and economic factors were also the determinants because the population in the city is already dense, and land prices in the city are unaffordable. Similarly, the respondents in Sindanglaya Village stated that economic factors, the need for housing, and the need for money drove the villagers to sell their land.

Factors of Land Conversion According to Communities in the Northern Suburbs of Bandung City (Lembang District)

According to the community in Lembang Subdistrict, Cikahuripan Village, various factors behind land conversion in the area are the presence of foreign land buyers, investors' willingness to pay high prices, entrepreneurs keen on building housing complexes or villas, and local population growth. Meanwhile, the respondents in Lembang Village reported two factors: the government regulation on the transfer of land functions and the need for housing.

The residents in Mekarwangi Village claimed that changing the function of agricultural land to non-agriculture was driven by the increasing number of residents, so that the need for housing also increased. In addition, the owner of agricultural land has the freedom to use or even sell their agricultural land. Other respondents said that the farmland owner initially mortgaged his agricultural land, but the land was eventually sold because the owner could not pay the loan. There is also an investor factor that changed the rice fields into the Dago Dream Park Tourism Area. The paddy field owner considered his agricultural land unproductive, so he sold the land to investors to become a tourist area. The respondents in Pagerwangi Village argued that the key factor behind land conversion was the government lenience on land use, in which the agricultural landowners may exercise their rights to use their land for various purposes. The respondents in Wangunsari Village stated that, due to the presence of foreign businesspeople, many people have invested in opening up business land in their village as factories or luxury residential complexes.

Factors behind Land Conversion by Communities in the Northern Suburbs of Bandung City (Parongpong District)

According to the community in Parongpong Subdistrict, Cihideung Village, among the land conversion factors is that landowners were lured by high land selling prices by investors. Due to economic factors, they were forced to sell land to meet their needs. Because of the population growth, the demand for housing increases, and the need for places of business likewise increases. In a similar vein, the respondents in Ciwarga Village echoed identical observations. They remarked that land conversion took place due to the rising need for places of living for incomers, residents' economic needs, and high land prices offered by investors.

\section{Community Responses in the Northern Suburbs of Bandung City to Land Conversion}

The community responses to land use conversion consisted of positive and negative responses. The positive responses varied to a certain extent. Land conversion was perceived as positive for land development, reducing wild animals so that the environment becomes safer. The residents' income increases as they can open businesses around settlements or tourist areas. The areas that were once deserted are now crowded with the opening of residential housing. Accessibility becomes easier, and the environment, such as gardens, fields, and dry fields close to the new settlements, is more well-maintained. The respondents stated that land use conversion is natural and inevitable because it is in line with population growth. Changes may be made if they follow and comply with 


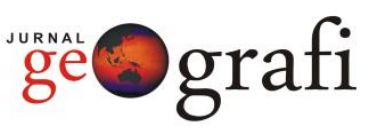

government regulations and plans, namely for protected and cultivated areas. Progress and modernization are the expected outcome of this land conversion.

The negative responses from the respondents varied. The temperature in the surrounding area is getting hotter. The natural landscape becomes arid, less green, and gets crowded with humans. The loss of agricultural land causes many farmers to be unemployed, and it is difficult for farmers to get a job. Rice fields as a source of food have disappeared. Settlements are built without permits. The loss of jobs in the agricultural sector leads to urbanization into cities for more opportunities. This conversion of agricultural land makes it difficult to obtain basic needs such as food and vegetables. In addition, the loss of green areas as water catchment areas has reduced water supply, making it difficult to obtain water. Poor people will find it harder to find land because many elite settlements have been built so that the price of land around it becomes expensive. As stated by Wardani et al. (2016), uncontrolled land use changes will cause social, economic, and environmental problems.

The northern suburbs of Bandung City, including the Districts of Lembang, Parongpong, and Cimenyan, are the main areas for groundwater recharge in the Bandung Basin. The existence of the Lembang, Parongpong, and Cimenyan areas plays a pivotal role as a provider of water reserves in the areas underneath, namely Bandung City and Cimahi City. Around 60\% of water sources in the Bandung Basin come from the northern suburbs of Bandung. However, regional developments in the three sub-districts have led to uncontrolled land conversion from agricultural land to built-up land. This conversion threatens its land function as a water catchment area and disrupts the balance of water resources for both the northern suburbs of Bandung City and the cities of Bandung and Cimahi. Therefore, any land conversion in the northern suburbs of Bandung City will affect the availability of groundwater in the surrounding area (West Java Provincial
Regulation Number 2 of 2016 concerning Guidelines for Controlling the North Bandung Region as a Strategic Area of West Java Province, 2016; Putri \& Purwadio, 2013).

Among the numerous factors affecting land use change is many incoming residents from outside the area, especially from Bandung City, due to the development of the surrounding area, namely Bandung City, and natural population growth in the area. The need for housing for residents and incoming residents coupled with population growth leads to a decrease in land.

The increasing rate of population growth in the city of Bandung is a challenge that must be faced today. This is because it has an effect on raising the need for land so that land prices in the city of Bandung are soaring. As a result, land once designated as a conservation area has been converted into a cultivation area. For the city residents who have economic constraints, they have no choice but to look for land in the suburbs of Bandung, where land prices are still relatively low (Prihatin, 2016). Four factors influence land use change, namely the proportion of the population working in the nonagricultural sector, population growth, and the distance of each village office to the center of population activity. The increase in the number of incomers and the distance of each village office to the center of population activity has a greater influence on changes in land use (Kusrini et al., 2011).

The incoming (foreign) investors to the area have prompted land use change in the northern suburbs of Bandung, in which they turned the land around the forest into a tourist area, villa, hotel, or elite settlements. The local residents were tempted by the prices offered by the investors because they were willing to pay high prices.

The high price of land offered to residents will affect the speed of land conversion because the higher the land price, the more the development in the future (Putri \& Purwadio, 2013). With many private parties buying productive land owned by the residents, it will elevate the price of the land. Investors usually need land to build 
settlements and trade such as shops, houses, malls, shopping centers, and tourism areas. The increasing need for land for economic activity centers is the same as the need for settlements, so that regional development in the city of Bandung will shift to suburban areas, one of which is in the North Bandung area (Prihatin, 2016).

The beautiful natural panorama with cool air and easy accessibility makes the northern suburbs of Bandung City extremely attractive to anyone, both residents, investors, and the government. Therefore, in the northern suburbs of Bandung, a broad range of activities have taken place, such as the establishment of housing, apartments, villas, resorts, hotels, and various tourist attractions. In addition, many offices and education/training centers for several government agencies have also been built (West Java Provincial Regulation Number 2 of 2016 concerning Guidelines for Controlling the North Bandung Area as a Strategic Area of West Java Province, 2016). The existence of tourist objects will attract investors and residents to build built-up land and take advantage of the existence of these attractions (Putri \& Purwadio, 2013).

In addition, relatively lower agricultural land prices drive land use change in the northern suburbs of Bandung. The growth of the industrial and service sectors has led to intense competition in land use. The increasing demands of industrial and service sectors escalate land prices, resulting in an increase in the conversion of agricultural land to non-agriculture (Jamal, 2001). There is a relationship between land use and land prices. Commercial and industrial land uses dominantly affect land prices, followed by land use for settlements, agriculture, forests, grasslands, and swamps (Prihatin, 2016).

The next factor affecting land conversion is that many children do not want to live far from their parents, so they look for land close to their parents' homes. When they feel at home, many local residents or even incomers will bring their relatives from other places to live in the area, making the population denser. The social character of the Sundanese people who are eager to gather (ngariung) will distort land prices in the market (Prihatin, 2016). This social outlook is reflected in their isiom "bengkung ngariung bongkok ngaronyok," which generally means that the Sundanese are culturally pleased to live with their extended family. This expression is wellfitted in rural communities that still have the flexibility to cultivate agricultural lands, such as rice fields, gardens, and even forests. By living with a large family, there will be much energy to help cultivate agricultural land (Sucipto et al., 2016).

Another factor influencing land use conversion is because the government allows the conversion of land functions. The area of Mount Tangkuban Parahu, which includes the Lembang District and its surroundings, is the most extensive zone for granting location permits. Until 1996, the government has issued permits to forty developers for an area of 2,163.59 hectares. Presently, there are 2,000 hectares of conservation land in Lembang District that have been occupied with buildings. This contrasts with the West Bandung Regency Spatial Plan, according to which only 1,035 hectares of land are permissible for conversion. This is because 2,000 hectares is a conservation area where the upstream river flows into the city of Bandung and Cimahi. This permit had led to uncontrolled development in the northern suburbs of Bandung City. This also signifies that the government has not examined the negative impacts of the development process (Putri \& Purwadio, 2013).

The other factor behind land use conversion is a greater degree of freedom on the part of the landowner to do anything with his/her land, whether it is to be sold, converted, mortgaged, or rented out. The traditional character of the community, such as not understanding the function of protected areas in water catchment areas, will affect the increase in land use conversion from water catchment areas to built land. This is due to public poverty of knowledge about the function of protected areas and the regulations regarding the 


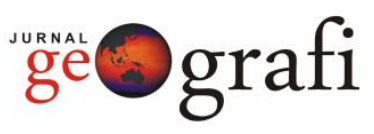

establishment of built-up land in protected areas. Hence, many people ended up selling their land for construction (Putri \& Purwadio, 2013).

The North Bandung area is rich in water sources, both from rainwater and springs. There are cases where some largevolume springs, which for years had been utilized by hundreds of families as a source of clean water, have now been sold by landowners to companies. More and more green lands have been converted into vegetable gardens and residential complexes. This causes rainwater to not seep into the ground so that some of the remaining springs undergo a decrease in discharge, especially during the dry season (Tri Joko Her Riadi, 2019). Population growth that requires space will change land use patterns, especially in the upper Citarum River basin. This land conversion leads to a reduction in water resources, thereby increasing the criticality of water ("Impact of land use conversion on the critical level of water in the upper Citarum sub-watershed," 2016).

Among the crucial factors of land conversion in the northern suburbs of Bandung is economy; that is, the sale can be used as business capital. This economic factor of rural communities in the city of Bandung made the local residents sells their land. This is because they could not meet their living needs through the agricultural sector. Thus, their land is sold to secure higher profits. The price of land used for nonagricultural purposes will be more expensive than land for agricultural activities. In addition, urban communities that do not have land for housing will look for land on the city's outskirts because the price is low. This resulted in the expansion of the city area to the outskirts of the city (Prihatin, 2016).

\section{CONCLUSION}

Based

on thefindings and discussions outlined above, it can be concluded that regional development was of the response positives, while the loss of land farming as a source of livelihood was among the negative responses. Findings revealed that of 108 respondents, $\quad 51.85 \% \quad$ provided positive responses, and the rest, $48.15 \%$, did otherwise over the conversion of land in North Bandung. Positive responses included that land conversion is suitable for regional development from the areas that were not crowded to become crowded; the construction of roads can improve access and mobility of the residents and improve the security of the surrounding environment; opening a tourist area can create job opportunities. Meanwhile, the negative responses, among others, were that land conversion could lead to rising temperature, barren fields, and humidity; it could also affect a shortage of water sources, and the loss of rice fields as a source of food, and farmers' loss of their livelihoods could cause plenty of unemployment.

Included in the factors for land use conversion were population growth of both residents and incoming residents, especially from the city of Bandung, the development of the Bandung city area that spreads to the northern suburbs of Bandung, increasing number of investors building residential and tourist areas, increased land prices, and socio-cultural factors of the Sundanese people eager to always gather with their families. The most crucial was the population factor, with a percentage level of $44.44 \%$, followed by the economic factor, $38.89 \%$. Meanwhile, environmental damage and regional autonomy were the least influential factors causing changes in land use with a percentage of $1.85 \%$.

\section{RECOMMENDATION}

Future research may undertake the mapping of land prices around the area of the outskirts of the north of Bandung as the impact of land function conversion. Given adverse effects, the government of Bandung Regency and West Bandung Regency are advised to safeguard the suburban areas of the northern city of Bandung from the uncontrollable land function conversion. 


\section{REFERENCES LIST}

As' ari, R., Mulyanie, E., \& Rohmat, D. (2019). Zonasi Pemanfaatan Lahan Pasca Penambangan Pasir di pesisir Cipatujah, Kabupaten Tasikmalaya, Jawa Barat. Jurnal Geografi, 11(2), 171181.

Berutu, D. S., \& Nurman, A. (2012). Aplikasi Penginderaan Jauh dan Sistem Informasi Geografis dalam Mengkaji Perubahan Luas Hutan di Kabupaten Kuantan Singingi (Riau) Tahun 20002010. Jurnal Geografi, 5(2), 189-198.

Latif, T. (2013). Dampak Perubahan Penggunaan Lahan terhadap Tingkat Kekritisan Air Sub-DAS Citarum Hulu. Majalah Geografi Indonesia.

Delita, F. (2016). Studi Perubahan Tutupan Lahan untuk Permukiman Sebelum dan Sesudah Gempa Padang 2009 di Kecamatan Koto Tangah Kota Padang Provinsi Sumatera Barat. Jurnal Geografi, 8(1).

Dewi, N. K., \& Rudiarto, I. (2013). Identifikasi alih fungsi lahan pertanian dan kondisi sosial ekonomi masyarakat daerah pinggiran di Kecamatan Gunungpati Kota Semarang. Jurnal Wilayah dan Lingkungan, 1(2), 175-188.

Giyarsih, S. R. (2010, July). Pola spasial transformasi wilayah di koridor Yogyakarta-Surakarta. In Forum Geografi (Vol. 24, No. 1, pp. 28-38).

Hossaimah, H., \& Subari, S. (2017). Percepatan alih fungsi (konversi) lahan pertanian ke non pertanian di Kecamatan Galis

Kabupaten

Pamekasan. Agrisaintifika: Jurnal IlmuIlmu Pertanian, 1(2), 97-108.

Mahdiyyah, N. D. (2019). Dampak Pertumbuhan Penduduk Terhadap Alih Fungsi Lahan Pertanian di Kabupaten Cirebon Tahun 2010-2016. Reka Geomatika, 2019(1).

Isa, I. (2006, June). Strategi pengendalian alih fungsi lahan pertanian. In Prosiding Seminar Multifungsi dan Revitalisasi Pertanian. A. Dariah, NL Nurida, E. Husen.

Jamal, E. (2001). Faktor-Faktor Yang Mempengaruhi Pembentukan Harga Lahan Sawah Pada Proses Alih Fungsi Lahan
Sawah Ke Penggunaan Non Pertanian: Studi Kasus Di Beberapa Desa, Kabupaten Karawang, Jawa Barat. Jurnal Agro Ekonomi, 19(1), 45-63.

Jannah, R., Eddy, B. T., \& Dalmiyatun, T. (2017). Alih fungsi lahan pertanian dan dampaknya terhadap kehidupan penduduk di kecamatan sayung kabupaten demak. Agrisocionomics: Jurnal Sosial Ekonomi Pertanian, 1(1), 1-10.

Kusrini, K., Suharyadi, S., \& Hardoyo, S. R. (2011). Perubahan Penggunaan Lahan dan Faktor yang Mempengaruhinya di Kecamatan Gunungpati Kota Semarang. Majalah Geografi Indonesia, 25(1), 25-40.

Lestari, W., \& Simanungkalit, N. M. (2012). Analisis Perubahan Penggunaan Lahan Wilayah Pesisir Desa Tanjung Rejo Kecamatan Percut Sei Tuan Kabupaten Deli Serdang (1990-2011). Jurnal Geografi, 4(2), 57-68.

Lumbantoruan, W. (2010). Studi Perkembangan Kota Medan Menggunakan Data Penginderaan Jauh Dan SIG. Jurnal Geografi, 2(2), 93-106.

Nurchamidah, L. (2017). Pengalih Fungsian Lahan Pertanian Ke Non Pertanian Di Kabupaten Tegal. Jurnal Akta,4(4), 699706.

Peraturan Gubernur Jawa Barat Nomor 30 Tahun 2008 Tentang Petunjuk Pelaksanaan Pengendalian Pemanfaatan Ruang Kawasan Bandung Utara di Wilayah Kabupaten Bandung dan Kabupaten Bandung Barat, (2008).

Peraturan Daerah Provinsi Jawa Barat Nomor 2 Tahun 2016 Tentang Pedoman Pengendalian Kawasan Bandung Utara Sebagai Kawasan Strategis Provinsi Jawa Barat, (2016).

Peraturan Rencana Pembangunan Jangka Panjang Daerah Kabupaten Bandung Tahun 2005 - 2025, (2005).

Prihatin, R. B. (2015). Alih Fungsi Lahan di Perkotaan (Studi Kasus di Kota Bandung dan Yogyakarta). Aspirasi: Jurnal Masalah-masalah Sosial, 6(2), 105-118.

Purwanti, T. (2020). Petani, Lahan dan Pembangunan: Dampak Alih Fungsi Lahan terhadap Kehidupan Ekonomi 
Petani. Umbara, 3(2), 95-104.

Putri, N. P., \& Purwadio, H. (2013). Arahan Pengendalian Alih Fungsi Daerah Resapan Air Menjadi Lahan Terbangun di Kecamatan Lembang, Bandung. Jurnal Teknik Pomits.

Rachma, I. O. N. (2016). Evaluasi Alih Fungsi Lahan Pertanian Menjadi Perumahan Di Kota Bandung Tahun 2011 s/d 2015. Universitas Gadjah Mada.

Sucipto, T., Makmur, A., Riawati, S., Rudito, B., Zaini Alif, M., \& Permadi, T. (2016). Analisis Konteks Pengetahuan Tradisional Dan Ekspresi Budaya Tradisional Berbasis Muatan Lokal Di Jawa Barat. Direktorat Kepercayaan Terhadap Tuhan Yme Dan Tradisi Direktorat Jenderal Kebudayaan
Kementrian Pendidikan Dan Kebudayaan. Sumaryanto, S. F., \& Irawan, B. (2001). Konversi Lahan Sawah ke Penggunaan Non Pertanian dan Dampak Negatifnya. In Prosiding Seminar Nasional Multifungsi Lahan Sawah (pp. 1-18).

Tri Joko Her Riadi. (2019, November). Angin Perubahan Dari Perbukitan Cimenyan Kabupaten Bandung. Pikiran Rakyat.

Wardani, D. W., Danoedoro, P., \& Susilo, B. (2016). Kajian perubahan penggunaan lahan berbasis citra penginderaan jauh resolusi menengah dengan Metode Multi Layer Perceptron dan Markov Chain. Majalah Geografi Indonesia, 30(1), 9-18. 